\title{
Application of Antimicrobial Nanoparticles in Dentistry
}

\author{
Wenjing Song ${ }^{1,2}$ and Shaohua Ge $\mathrm{e}^{1,2, *(\mathbb{D})}$ \\ 1 Shandong Provincial Key Laboratory of Oral Tissue Regeneration, School of Stomatology, Shandong \\ University, Jinan 250012, China; wenjing9207@163.com \\ 2 Department of Periodontology, School of Stomatology, Shandong University, Jinan 250012, China \\ * Correspondence: shaohuage@sdu.edu.cn; Tel.: +86-(0531)-8838-2123
}

Academic Editor: Franco Dosio

Received: 20 February 2019; Accepted: 8 March 2019; Published: 15 March 2019

\begin{abstract}
Oral cavity incessantly encounters a plethora of microorganisms. Plaque biofilm-a major cause of caries, periodontitis and other dental diseases-is a complex community of bacteria or fungi that causes infection by protecting pathogenic microorganisms from external drug agents and escaping the host defense mechanisms. Antimicrobial nanoparticles are promising because of several advantages such as ultra-small sizes, large surface-area-to-mass ratio and special physical and chemical properties. To better summarize explorations of antimicrobial nanoparticles and provide directions for future studies, we present the following critical review. The keywords "nanoparticle," "anti-infective or antibacterial or antimicrobial" and "dentistry" were retrieved from Pubmed, Scopus, Embase and Web of Science databases in the last five years. A total of 172 articles met the requirements were included and discussed in this review. The results show that superior antibacterial properties of nanoparticle biomaterials bring broad prospects in the oral field. This review presents the development, applications and underneath mechanisms of antibacterial nanoparticles in dentistry including restorative dentistry, endodontics, implantology, orthodontics, dental prostheses and periodontal field.
\end{abstract}

Keywords: application; antimicrobial; nanoparticles; dentistry

\section{Introduction}

The oral cavity constantly encounters a plethora of microorganisms [1]. Plaque biofilm-a major cause of caries, periodontitis and other dental diseases-is a complex community of bacteria or fungi that causes infection by protecting pathogenic microorganisms from external drug agents and escaping the host defense mechanisms [2]. Although significant numbers of study that focus on developing antimicrobial agents to overcome this problem exist, most of these attempts failed to achieve desired outcomes due to the rapid degradation and fast release of antibacterial agents causing low efficiency and safety concerns [3,4].

Nanomaterials usually refer to tiny solid particles with a diameter of 1-100 nm. Nanomaterials are promising in antibacterial therapies because of their enhanced and unique physicochemical properties such as ultra-small sizes, large surface-area-to-mass ratio and increased chemical reactivity [3]. Nanoparticles (NPs) may provide a new strategy for treating and preventing dental infections [5]. The large surface area and high charge density of NPs enable them to interact with the negatively-charged surface of bacterial cells to a greater extent resulting in enhanced antimicrobial activity [6]. Moreover, NPs combined with polymers or coated onto biomaterial surfaces was found to exhibit superior antimicrobial properties in the oral cavity [3].

Metal and organic NPs have been applied in several areas of dentistry because of their broad-spectrum bactericidal properties [5]. Smaller NPs could release their corresponding ions more 
to obtain a better antibacterial effect. Many kinds of research focused on the antibacterial properties of NPs and showed that NPs possessed superior antibacterial activity in bacteria of drug resistance $[1,2,4]$. Thus, the application of nanoparticles in dentistry might be particularly advantageous.

This paper aims to present a comprehensive review (Figure 1) on the development and application of antibacterial NPs in dentistry including restorative dentistry, endodontics, implantology, dental prostheses, orthodontics and periodontal field.

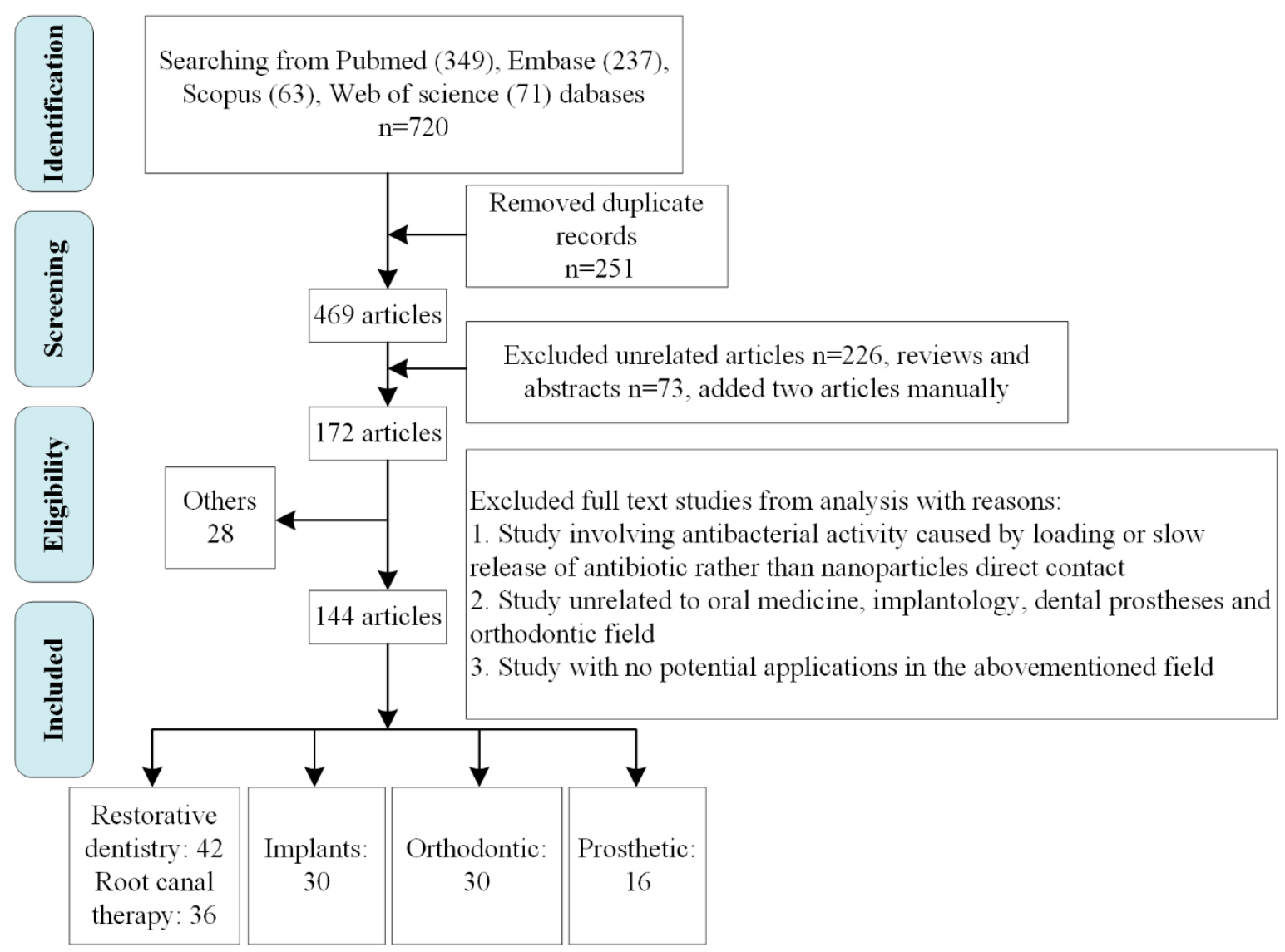

Figure 1. Inclusion/exclusion criteria and study flow for the systematic review.

\section{Antimicrobial Applications in Dentistry}

\subsection{Antimicrobial Activity in Oral Medicine}

\subsubsection{Restorative Dentistry}

Dental caries is one of the most common infectious diseases in the oral cavity, which is usually repaired with materials of which the color is similar to that of the teeth. However, the failure of restoration or the formation of secondary caries can occur because of the lacking of antibacterial properties and demineralization caused by microorganisms and microbial acid production [1].

The development of nanotechnology has arisen the interests of many researchers. There are two methodologies to resist dental caries. The first method is incorporating inorganic antibacterial NPs into resin composites and agents to reduce microorganism biofilm with direct contact [7-17]. Composite resins containing 1\% silver nanoparticles (AgNPs) or zinc oxide nanoparticles (ZnO NPs) exhibited a better antibacterial activity. Note that the antibacterial effect of composite resin containing ZnO NPs on Streptococcus mutans (S. mutans) was significantly higher than that containing AgNPs $[1,18,19]$. Additionally, S. mutans activity could be significantly inhibited by AgNPs which was formed in situ via a photoreduction mechanism concomitant to the polymerization reaction [3]. 
Even dental resins containing a low concentration of novel nanofillers possessed adequate and long-term antimicrobial properties [4]. An amount of $1 \mathrm{wt} \%$ quaternized copolymer functionalized nanodiamond-reinforced resin composites effectively inhibited the formation of biofilm without cytotoxicity [6]. However, some researches related to the resin luting cements with AgNPs addition and dental sealants modified with nylon- 6 and chitosan nanofibers did not show an antibacterial effect against $S$. mutans $[5,20]$. The cooperation of graphite oxide, AgNPs and phthalocyanine molecules promoted lasting disinfection in the presence of near-infrared irradiation [21]. The form of colloidal metal oxide NPs was also proven to have superior antibacterial activity [22].

Glass ionomer cements (GICs) with a good fluoride-ion release function have been applied to prevent and reduce the occurrence of secondary caries [23]. The copper-doped glass ionomer-based materials greatly enhanced their antibacterial properties and reduced collagen degradation [24]. The addition of titanium dioxide $\left(\mathrm{TiO}_{2}\right) \mathrm{NPs}$ significantly improved mechanical and antibacterial activity [25]. Hexametaphosphate NPs incorporated in GICs effectively improved antibacterial properties and enhanced fluoride ion release [26]. Nevertheless, ZnO NPs as an additive into GICs could not promote the antimicrobial activity against S. mutans [27].

The second methodology is the usage of organic NPs to reduce demineralization and achieve remineralization. The nanoparticles of amorphous calcium phosphate (NACP) combined with polymerizable quaternary ammonium methacrylates (QAMs), such as quaternary ammonium polyethyleneimine (QPEI) [28], quaternary ammonium dimethacrylate (QADM) [29], dimethylaminohexadecyl methacrylate (DMAHDM) [7,30-35] and organic antibacterial NPs [36-39] was researched. Modified composite incorporating QPEI NPs had excellent antibacterial activity and long-term durability [28]. A composite containing both QADM and AgNPs possessed a stronger antibacterial capability, which lasts for 12 months of water-aging [29]. Antibacterial bonding agents containing DMADDM and AgNPs greatly inhibited biofilm activities such as reducing the metabolic activity, colony forming unit (CFU) and lactic acid of microcosm biofilms, even when the dental adhesive was pre-coated with salivary pellicles [36].

The combination of DMAHDM, 2-methacryloyloxyethyl phosphorylcholine (MPC) and NACP was also researched [29-32,40-42]. MPC, one of the most common biocompatible and hydrophilic biomedical polymers, was incorporated into dentin bonding agents and composites due to its hydrophilicity that prevents the adsorption of proteins [32,33]. NACP could release a high level of $\mathrm{Ca}$ and $\mathrm{P}$ ions, neutralize acids, and inhibit dental caries by matching mechanical properties when containing into resin composites [30-32].

A new rechargeable NACP composite with multiple re-release capability was developed for long-term caries inhibition [33]. The methodologies of using NACP, MPC and DMAHDM may be applicable to other dental composites, adhesives and cements to reduce the formation of plaque biofilm in restorative dentistry.

\subsubsection{Root Canal Therapy}

Long-term or secondary dental caries may lead to pulpitis and apical periodontitis which are mainly caused by bacteria and their products. Enterococcus faecalis (E. faecalis) is mainly responsible for reinfections after root canal therapy [43-45]. Complex root canal anatomy makes the complete microbial cleanup particularly difficult, even with a thorough root canal preparation and filling [46,47].

The application of NPs has attracted researchers' attention [43,48-51]. Biosynthesized AgNPs had an antimicrobial ability against E. faecalis [52-54]. Afkhami et al. reported that irrigant with $100 \mathrm{ppm}$ AgNPs solution had better antimicrobial efficacy than $2.5 \%$ sodium hypochlorite (NaOCl) [55]. Poly (vinyl alcohol)-coated AgNPs (AgNPs-PVA) and farnesol (FAR) were not only more favorable for tissue repair and but also less cytotoxic in comparison with $\mathrm{NaOCl}$ [56]. Compared to $5.25 \% \mathrm{NaOCl}$, nano-MgO (5 mg/L) and chitosan NPs exhibited statistically significant long-term efficiency in the elimination of $E$. faecalis in the root canal system $[57,58]$. A previous study showed that the biomimetic 
iron oxide NPs with peroxidase-like activity enhanced antibacterial activity on root canal surfaces and in dentinal tubules [59].

The form of NPs may influence the antibacterial properties. Chlorhexidine (CHX)-AgNPs containing lyotropic liquid crystals (LLC) exhibited excellent and sustained sterilization and inhibitory effect on $E$. faecalis lasting for more than one month with a bacterial inactivation rate of $\geq 98.5 \%$. Besides, no toxicity was observed in the cytotoxicity evaluation [60]. However, the latest literature showed that AgNPs irrigant was less effective against E. faecalis biofilm and infected dentinal tubules than $\mathrm{NaOCl}$ [61], which was consistent with the result that AgNPs gel was more effective as irrigant agent than solution form [62]. Moreover, $\mathrm{NaOCl}$ has been the most efficient irrigating solution in root canal treatment [63].

It is essential to develop antibacterial root filling materials for endodontic treatment to prevent secondary infection [64-66]. The addition of 0.15\% AgNPs and 2.5\% DMAHDM did not adversely affect the physical properties of the AH Plus paste, furthermore, the paste with nano-fillers exhibited significantly higher antibacterial activity against E. faecalis [67]. Calcium hydroxide $\left(\mathrm{Ca}(\mathrm{OH})_{2}\right)$ is routinely used as an intracanal medicament in clinical practice. Incorporating chitosan NPs into a $\mathrm{Ca}(\mathrm{OH})_{2}$-based paste had the potential of increasing its antibacterial ability [68]. Both the nanoforms of $\mathrm{Ca}(\mathrm{OH})_{2}$ and chitosan showed superior penetration into the dentinal tubules and appreciable antibacterial efficacy [69-71].

The addition of NPs promoted antibacterial activity in $\mathrm{Ca}(\mathrm{OH})_{2}[72,73]$ and other filling materials [74-77]. Calcium silicate cement such as mineral trioxide aggregate (MTA) and Portland cement (PC) showed antimicrobial effects, and their antimicrobial activity was significantly enhanced by mixing them with different concentrations of AgNPs [75,78]. Similarly, the addition of QPEI NPS also reduced bacteria viability and promoted cell death $[48,76,79]$.

\subsection{Implants Modified with Antibacterial Nanoparticles}

A dental implant is one of the most common and recognized ways to repair missing teeth. Titanium (Ti) implants are widely used in dentistry, for the high strength, durability and biocompatibility [80]. The failure of implantation is caused by the accumulation of plaque biofilm in the oral cavity during the early and healing stage. Implant infections usually include peri-implant mucositis and peri-implantitis, with incidences increasing dramatically [80,81]. The pathogenesis of dental peri-implantitis is similar to periodontitis, which is characterized by a high prevalence of Gram-negative anaerobes [81].

Among the sources of infections, Staphylococcus aureus (S. aureus), S. mutans and Escherichia coli were the principal bacterial strains to be found and tested [82-84]. Pathogenic bacteria/fungi such as Porphyromonas gingivalis (Pg) [85-87], Aggregatibacter actinomycetemcomitansand (Aa) [88], Candida albicans (C. albicans) [89] were also used as targets in a model of simulated implant infection. It is crucial to develop alternative implant materials with antibacterial ability to prevent and reduce bacterial-associated implant failure [80].

Different antimicrobial NPs were developed such as Ag [89-96], copper (Cu) [95], ZnO [87,97,98], titanium dioxide $\left(\mathrm{TiO}_{2}\right)$ [99-101] and selenium (Se) [102]. AgNPs showed significant antimicrobial activity against Gram-negative and Gram-positive bacteria [86,103]. Ti surface loaded with 0.05 ppm AgNPs was sufficient to inhibit Gram-positive and Gram-negative species, and the latter was more susceptible to AgNPs. However, the NPs applied in this study exhibited cytotoxicity on osteoblasts, thus limited its clinical application [91]. Ag plasma immersion ion implantation-treated Ti surface showed a higher inhibitory effect on Fusobacterium nucleatum (Fn) than S. aureus [94].

Ti substrates combination with hydroxyapatite [103] or chitosan NPs [85,104], surface modification of Ti-implants [83,87,105-108] and application of composite coating [82,104,109] exhibited superior antibacterial activity and better biocompatibility. Zhong et al. [104] prepared a phase-transited lysozyme (PTL)-hyaluronic acid-chitosan/nano-Ag composite coating on Ti surface by the layer-by-layer self-assembly method. At the first four days, the inhibition rate against S. aureus 
was close to $100 \%$ and kept in the range of $65-90 \%$ after two weeks. Therefore, Ti modified with coatings could keep a strong and stable antibacterial activity for a long time.

$\mathrm{TiO}_{2}$ nano-array modified Ti substrate prepared by our group was found to promote the adhesion, proliferation and osteogenic differentiation of human periodontal ligament stem cells. In addition, $\mathrm{TiO}_{2}$ nanorod arrays (TNRs) exhibited superior antifungal/antibacterial properties $[105,106]$. The preliminary results showed that surface-area-to-mass ratio, roughness and hydrophilicity were improved and enhanced after modification with TNRs [105]. More importantly, TNRs presented significantly higher antifungal (C. albicans) and antibacterial ( $A a$ and $P g$ ) activity toward both biofilm and planktonic states than pure Ti after ultraviolet (UV) irradiation [106]. Cu [83,110], ZnO [87,97,98] and Se [102] also imparted certain antibacterial properties to implanting materials.

At present, most of the studies have been carried out in vitro or in vivo. The effect of nanoparticle-modified implants on human micro-environment and the size, loading doses as well as bio-safety of various NPs have yet to be further investigated.

\subsection{Orthodontics}

Fixed orthodontic appliances/treatments are inclined to plaque biofilm accumulation and enhance the chance of enamel demineralization (also called white spot lesions, WSLs), which is the initial performance of dental caries due to organic acid produced by the biofilm of microorganisms [111,112]. Though oral hygiene education and mechanical therapy can prevent and remove the plaque biofilm, more effective methods should be developed to prevent WSLs with long-term anti-adhesion and antibacterial properties independent of patient's cooperation [111,113].

Studies showed that the addition of antimicrobial NPs to orthodontic adhesive agents [111,114-122] and resin-modified glass ionomers cements (RMGICs) [112,121-123] might prevent plaque accumulation and bacterial adhesion. Sodagar et al. showed that all experimental groups reduced the viable bacterial count by comparing to the control group, $5 \% \mathrm{Ag} /$ hydroxyapatite nano-fillers had good antibacterial properties and shear bond strength [116]. The addition of CuO NPs promoted the antimicrobial property without adverse effects on shear bond strength [111]. On the contrary, the addition of $\mathrm{TiO}_{2} \mathrm{NPs}$ presented better antimicrobial activity while weakening the shear bond strength [114]. RMGICs were widely used in orthodontic appliances due to their outstanding fluoride ions release [121,122]. MPC, DMAHDM, AgNPs and NACP were separately incorporated into RMGICs and all obtained optimal antibacterial results [112,121-123]. A novel multifunctional orthodontic cement which was developed with strong antibacterial effect could inhibit bacteria on the cement and in the vicinity away from the brackets [112,123].

Nanotechnology was also applied to orthodontic accessories such as brackets [113,124], orthodontic wires/ligatures [125-128], micro-implants [129] and orthodontic retainers [130] since biofilms are more prone to aggregate on the surfaces of irregular structures. Evidence showed that the addition of $\mathrm{CuO}$ NPs and $(\mathrm{CuO}-\mathrm{ZnO}) \mathrm{NPs}$ had a better antimicrobial effect and control than $\mathrm{ZnO}$ NPs groups [124]. Animal experiments showed that AgNPs coated brackets effectively inhibited the growth of S. mutans up to 45 days without cytotoxicity [113]. Nickel-Titanium (NiTi) and stainless-steel archwires modified with antibacterial NPs of $\mathrm{Ag}$ and $\mathrm{ZnO}$ exhibited excellent antibacterial activity and biocompatibility $[127,128]$. In the debonding stage in vivo, the addition of AgNPs into orthodontic retainers had a strong antimicrobial effect against $S$. mutans [130].

\subsection{Other Applications}

\subsubsection{Antimicrobial Application in Prosthetic Fields}

Wearing removable/complete dentures for a long term is prone to microbial aggregation, which can lead to denture stomatitis [131]. Polymethyl methacrylate (PMMA) has been the most common utilized biomaterial for removable partial or complete dentures, although it exhibits relatively poor antimicrobial properties [132]. 
Various nanofillers have been incorporated into biomaterials to improve antibacterial activity. The addition of inorganic NPs such as Ag [133-136], platinum [137], Zn/ZnO [138], Ti/ $\mathrm{TiO}_{2}$ [139-141] and zirconium oxide $\left(\mathrm{ZrO}_{2}\right)[142,143]$ exerted excellent antibacterial effects. $\mathrm{TiO}_{2} \mathrm{NPs}$ have a large spectrum of activity against microorganisms including Gram-negative and Gram-positive bacteria and fungi [140]. Additionally, $\mathrm{TiO}_{2} \mathrm{NPs}$ improved the antimicrobial behavior of PMMA by significantly reducing bacterial adherence as $\mathrm{TiO}_{2}$ ratio increased [139]. PMMA incorporation with the nanofillers of $\mathrm{TiO}_{2}$ and silicon dioxide mixture had a superior antibacterial activity under UV, which could degrade microorganisms with prolonged exposure [144]. A study compared four inorganic antibacterial materials and showed that $3 \mathrm{wt} \%$ Ag-supported $\mathrm{Zr}$ phosphate (Navaron) and tetrapod-like zinc oxide whiskers ( $\mathrm{T}-\mathrm{ZnOw}$ ) in $\mathrm{ZrO}_{2}$-Silanized aluminum borate whiskers (ABWs)/PMMA composites possessed substantially higher antibacterial activity and exhibited no cytotoxicity, even though the filler of $\mathrm{TiO}_{2} \mathrm{NPs}$ and $\left(\mathrm{Ag} / \mathrm{TiO}_{2}\right) \mathrm{NPs}$ were slightly cytotoxic [141].

Non-metallic NPs possess powerful antibacterial properties. CHX-NP-coated silicone specimens exhibited antifungal action while CHX-hexametaphosphate (HMP) showed slow, sustained antibacterial properties [145]. As organic polymers, chitosan and graphene oxide are well known for their antibacterial properties. The application of chitosan NPs effectively inhibited fungal and bacterial growth within 48 hours [131]. Graphene oxide incorporated into PMMA had long term antimicrobial-adhesive effects without compromising mechanical properties [146]. However, the black color of graphene oxide limited its clinical application.

In summary, the current NPs still have certain disadvantages. In the future, antibacterial nanomaterials with excellent mechanical and aesthetic functions are expected to be developed and applied in clinical practice.

\subsubsection{Periodontics and Preventive Medicine}

Periodontitis is a type of bacterial infectious disease caused by microorganisms. The new composite consisted of DMAHDM, MPC and NACP effectively inhibited the recognized periodontitis-related pathogens without compromising the mechanical properties [147-150]. Studies in vitro showed that the mouthwash solution containing $\mathrm{TiO}_{2} \mathrm{NPs}$ showed superior antibacterial activity against oral pathogenic microorganisms [151]. Nanoparticles of Zn [152,153], Ag [2,154-160] synergistic with CHX [161,162] or doxycycline [163] showed significant antibacterial effect in an in vitro subgingival biofilm mode. Hexagonal form of boron nitride (hBN)—referred as "white graphite"—showed high antibiofilm activity on preformed biofilm and exhibited no cytotoxic effect on cells at the concentration range of $0.025-0.1 \mathrm{mg} / \mathrm{mL}$ [164].

In addition to active and effective antibacterial treatment, NPs also play a major role in the field of prevent the oral diseases. Nanoparticles of sodium fluoride (NSF) fluoride-based varnishes showed expected antibacterial effects when compared to silver diamine fluoride (SDF) varnishes-the gold standard for anticariogenic agents [165-167]. The toothbrush impregnated with AgNPs reduced the number of the putative periodontal pathogens $[168,169]$. The abovementioned methods can be applied to prevent the early childhood pit and fissure caries.

At present, the primary purpose of research on periodontitis and oral prevention is to achieve the long-term sustained antibacterial effect, and researchers mainly focused on the loading and sustained release of NPs on drugs [170-172].

\section{Antibacterial Mechanism}

Nanoparticles are capable of attaching and penetrating cell walls of both Gram-positive and Gram-negative bacteria, which disturbs cell function by releasing related ions [4]. Therefore, NPs are advantageous for the prevention and treatment of diseases caused by drug-resistant microorganisms and inhibition of biofilm formation.

The antibacterial mechanism of NPs can be roughly divided into three types although the specific mechanism of action is not yet clear. The antibacterial mechanisms are described as follows: (1) 
interacting with peptidoglycan cell wall and membrane and causing cell lysis; (2) interacting with bacterial proteins and disrupting protein synthesis; (3) interacting with bacterial (cytoplasmic) DNA and preventing DNA replication [4,120,141].

As the representative of inorganic NPs, AgNPs have been reported to interact with the abovementioned structures to inhibit respiratory chain enzymes and to interfere with membrane permeability. AgNPs could convert oxygen into active oxygen by its catalytic action leading to the structural damage of the microorganisms, which is called the "oligodynamic action" of Ag [133].

As the representative of organic NPs, chitosan is a derivative of chitin, the second most abundant natural biopolymer. Chitosan is biocompatible and biodegradable, and possesses a broad range of antimicrobial activity [56]. Moreover, chitosan NPs are inferred to have a similar antibacterial mechanism as AgNPs.

Despite the significant antibacterial activity of NPs, limitations for application still exist, which include inconsistent antibacterial concentrations against micro-biofilm, toxicity and potentially undesirable effects on the human body.

\section{Toxicity}

The toxicity of NPs may be influenced by many factors. Some studies did not explore the toxicity of NPs $[18,45,64,67,124]$, while others showed that NPs with antibacterial properties did not exhibit cytotoxicity within a certain concentration ranges [11,57,80,92,94,101,115,120,146,154,164]. Not surprisingly, low concentration NPs with antibacterial properties were non-toxic while the high-concentration ones exhibited more pronounced cytotoxicity [110], and even some researchers found that the toxicity of NPs exhibited a dose-dependent effect $[6,9,159]$.

However, there are other sounds according to the toxicity of NPs $[19,60,95,141]$. A previous study found that the toxicity of NPs had a strong correlation with the time, rather than with the concentration of antimicrobial NPs [19]. A favorable outcome was that the addition of antibacterial NPs made the original materials less toxic but more biocompatible $[60,84,90]$. In summary, the toxicity of antimicrobial NPs is affected by a variety of factors such as dosage, types, particle size, distribution, duration of action, interaction with other components and so on.

NPs can easily enter the body and accumulate in organs leading to symptoms of poisoning due to the extremely small particle size. To date, no study has been conducted to test the cytotoxicity of NPs on human beings. Additionally, though a few pieces of research have explored the antibacterial toxicity of different NPs $[50,141]$, there are no uniform indicators to standardize the toxicity of antibacterial NPs. As a result, it is difficult to compare the toxicity among different NPs. The toxicity of antimicrobial NPs is worthy of being explored in the same condition in dentistry.

\section{Conclusions}

In this review, applications of antibacterial NPs in dentistry are explored. The antibacterial mechanisms and bio-safety are also discussed. Our results illustrate that antimicrobial NPs have wide ranges of applications in restorative dentistry, endodontics, implantology, dental prostheses, orthodontics and other dental fields. NPs have an excellent antibacterial effect, but their antibacterial properties are affected by the concentration, type, form and other factors. The specific antibacterial mechanism and toxicity are not yet clear, and thus further research is needed to address the exact mechanism. Two limitations in the present study should be highlighted. Firstly, the applications of antimicrobial NPs in dentistry are not completely discussed in this review, as only the papers published during the last five years are included. Secondly, language bias might exist since only papers published in English are included.

Author Contributions: Conceptualization S.G.; writing—original draft preparation, W.S.; writing-review, editing and supervision, S.G. All authors have read the manuscript before submission. 
Funding: This research was funded by [National Natural Science Foundation of China] grant number [81670993 and 81873716], [Key Research and Development Program of Shandong Province] grant number [2018GSF118065], [The Fundamental Research Funds of Shandong University] grant number [2018JC005], [Medical and Health Science and Technology Development Program of Shandong Province] grant number [2016WS0339], [The National Key Research and Development Program of China] grant number [2017YFA0104604].

Conflicts of Interest: The authors declare no conflicts of interest.

\section{References}

1. Kasraei, S.; Sami, L. Antibacterial properties of composite resins incorporating silver and zinc oxide nanoparticles on Streptococcus mutans and Lactobacillus. Restor. Dent. Endod. 2014, 39, 109-114. [CrossRef] [PubMed]

2. Fernandes, G.L.; Delbem, A.C.B. Nanosynthesis of Silver-Calcium Glycerophosphate: Promising Association against Oral Pathogens. Antibiotics (Basel) 2018, 7, 52. [CrossRef] [PubMed]

3. Saafan, A.; Zaazou, M.H. Assessment of Photodynamic Therapy and Nanoparticles Effects on Caries Models. Open Access Maced. J. Med. Sci. 2018, 6, 1289-1295. [CrossRef] [PubMed]

4. Cao, W.; Zhang, Y. Development of a novel resin-based dental material with dual biocidal modes and sustained release of $\mathrm{Ag}+$ ions based on photocurable core-shell $\mathrm{AgBr} /$ cationic polymer nanocomposites. J. Mater. Sci. Mater. Med. 2017, 28. [CrossRef] [PubMed]

5. Magalhaes, A.P.; Moreira, F.C. Silver nanoparticles in resin luting cements: Antibacterial and physiochemical properties. J. Clin. Exp. Dent. 2016, 8, e415-e422. [CrossRef] [PubMed]

6. Cao, W.; Zhang, Y. Novel resin-based dental material with anti-biofilm activity and improved mechanical property by incorporating hydrophilic cationic copolymer functionalized nanodiamond. J. Mater. Sci. Mater. Med. 2018, 29, 162. [CrossRef]

7. Xie, X.; Wang, L. Novel dental adhesive with triple benefits of calcium phosphate recharge, protein-repellent and antibacterial functions. Dent. Mater. 2017, 33, 553-563. [CrossRef] [PubMed]

8. Gutierrez, M.F.; Malaquias, P. The role of copper nanoparticles in an etch-and-rinse adhesive on antimicrobial activity, mechanical properties and the durability of resin-dentine interfaces. J. Dent. 2017, 61, 12-20. [CrossRef]

9. Alberto Perez-Diaz, M.; Boegli, L. Silver nanoparticles with antimicrobial activities against Streptococcus mutans and their cytotoxic effect. Mater. Sci. Eng. C Mater. Biol. Appl. 2015, 55, 360-366. [CrossRef]

10. Cai, Y.; Stromme, M. Photocatalytic inactivation of biofilms on bioactive dental adhesives. J. Biomed. Mater. Res. B Appl. Biomater. 2014, 102, 62-67. [CrossRef]

11. Sabatini, C.; Mennito, A.S. Incorporation of bactericidal poly-acrylic acid modified copper iodide particles into adhesive resins. J. Dent. 2015, 43, 546-555. [CrossRef] [PubMed]

12. Cataldi, A.; Gallorini, M. Adhesion of human gingival fibroblasts/Streptococcus mitis co-culture on the nanocomposite system Chitlac-nAg. J. Mater. Sci. Mater. Med. 2016, 27, 88. [CrossRef] [PubMed]

13. Gao, L.; Liu, Y. Nanocatalysts promote Streptococcus mutans biofilm matrix degradation and enhance bacterial killing to suppress dental caries in vivo. Biomaterials 2016, 101, 272-284. [CrossRef] [PubMed]

14. Gutierrez, M.F.; Malaquias, P. Mechanical and microbiological properties and drug release modeling of an etch-and-rinse adhesive containing copper nanoparticles. Dent. Mater. 2017, 33, 309-320. [CrossRef] [PubMed]

15. Liu, Y.; Naha, P.C. Topical ferumoxytol nanoparticles disrupt biofilms and prevent tooth decay in vivo via intrinsic catalytic activity. Nat. Commun. 2018, 9. [CrossRef]

16. Elgamily, H.M.; El-Sayed, H.S. The Antibacterial Effect of Two Cavity Disinfectants against One of Cariogenic Pathogen: An In vitro Comparative Study. Contemp. Clin. Dent. 2018, 9, 457-462. [CrossRef] [PubMed]

17. Esteban Florez, F.L.; Hiers, R.D. Antibacterial dental adhesive resins containing nitrogen-doped titanium dioxide nanoparticles. Mater. Sci. Eng. C Mater. Biol. Appl. 2018, 93, 931-943. [CrossRef]

18. Andrade, V.; Martinez, A. Antibacterial activity against Streptococcus mutans and diametrical tensile strength of an interim cement modified with zinc oxide nanoparticles and terpenes: An in vitro study. J. Prosthet. Dent. 2018, 119, 862.e1-862.e7. [CrossRef]

19. Dutra-Correa, M.; Leite, A. Antibacterial effects and cytotoxicity of an adhesive containing low concentration of silver nanoparticles. J. Dent. 2018, 77, 66-71. [CrossRef] 
20. Hamilton, M.F.; Otte, A.D. Physicomechanical and antibacterial properties of experimental resin-based dental sealants modified with nylon- 6 and chitosan nanofibers. J. Biomed. Mater. Res. B Appl. Biomater. 2015, 103, 1560-1568. [CrossRef]

21. Gerasymchuk, Y.; Lukowiak, A. New photosensitive nanometric graphite oxide composites as antimicrobial material with prolonged action. J. Inorg. Biochem. 2016, 159, 142-148. [CrossRef]

22. Karasenkov, Y.; Frolov, G. Colloidal metal oxide nanoparticle systems: The new promising way to prevent antibiotic resistance during treatment of local infectious processes. In 3rd International Youth Conference on Interdisciplinary Problems of Nanotechnology, Biomedicine and Nanotoxicology; Refsnes, M., Gusev, A., Godymchuk, A., Bogdan, A., Eds.; IOP Conference Series-Materials Science and Engineering; IOP Publishing Ltd: London, UK, 2015.

23. Paiva, L.; Fidalgo, T.K.S. Antibacterial properties and compressive strength of new one-step preparation silver nanoparticles in glass ionomer cements (NanoAg-GIC). J. Dent. 2018, 69, 102-109. [CrossRef]

24. Renne, W.G.; Lindner, A. Antibacterial properties of copper iodide-doped glass ionomer-based materials and effect of copper iodide nanoparticles on collagen degradation. Clin. Oral Investig. 2017, 21, 369-379. [CrossRef]

25. Garcia-Contreras, R.; Scougall-Vilchis, R.J. Mechanical, antibacterial and bond strength properties of nano-titanium-enriched glass ionomer cement. J. Appl. Oral Sci. 2015, 23, 321-328. [CrossRef]

26. Hosida, T.Y.; Delbem, A.C.B. Ion release, antimicrobial and physio-mechanical properties of glass ionomer cement containing micro or nanosized hexametaphosphate, and their effect on enamel demineralization. Clin. Oral Investig. 2018. [CrossRef]

27. Garcia, P.; Cardia, M.F.B. Antibacterial activity of glass ionomer cement modified by zinc oxide nanoparticles. Microsc. Res. Tech. 2017, 80, 456-461. [CrossRef]

28. Pietrokovski, Y.; Nisimov, I. Antibacterial effect of composite resin foundation material incorporating quaternary ammonium polyethyleneimine nanoparticles. J. Prosthet. Dent. 2016, 116, 603-609. [CrossRef]

29. Cheng, L.; Zhang, K. One-year water-ageing of calcium phosphate composite containing nano-silver and quaternary ammonium to inhibit biofilms. Int. J. Oral Sci. 2016, 8, 172-181. [CrossRef]

30. Wu, J.; Zhou, H. Effect of dimethylaminohexadecyl methacrylate mass fraction on fracture toughness and antibacterial properties of CaP nanocomposite. J. Dent. 2015, 43, 1539-1546. [CrossRef]

31. Yue, S.; Wu, J. Novel dental adhesive resin with crack self-healing, antimicrobial and remineralization properties. J. Dent. 2018, 75, 48-57. [CrossRef]

32. Zhang, N.; Melo, M.A. Development of a multifunctional adhesive system for prevention of root caries and secondary caries. Dent. Mater. 2015, 31, 1119-1131. [CrossRef]

33. Xie, X.; Wang, L. Protein-repellent and antibacterial functions of a calcium phosphate rechargeable nanocomposite. J. Dent. 2016, 52, 15-22. [CrossRef]

34. Al-Dulaijan, Y.A.; Cheng, L. Novel rechargeable calcium phosphate nanocomposite with antibacterial activity to suppress biofilm acids and dental caries. J. Dent. 2018, 72, 44-52. [CrossRef]

35. Ibrahim, M.S.; AlQarni, F.D. Tuning Nano-Amorphous Calcium Phosphate Content in Novel Rechargeable Antibacterial Dental Sealant. Materials (Basel) 2018, 11, 1544. [CrossRef]

36. Li, F.; Weir, M.D. Effect of salivary pellicle on antibacterial activity of novel antibacterial dental adhesives using a dental plaque microcosm biofilm model. Dent. Mater. 2014, 30, 182-191. [CrossRef]

37. Aliasghari, A.; Khorasgani, M.R. Evaluation of antibacterial efficiency of chitosan and chitosan nanoparticles on cariogenic streptococci: An in vitro study. Iran. J. Microbiol. 2016, 8, 93-100.

38. Wassel, M.O.; Khattab, M.A. Antibacterial activity against Streptococcus mutans and inhibition of bacterial induced enamel demineralization of propolis, miswak, and chitosan nanoparticles based dental varnishes. J. Adv. Res. 2017, 8, 387-392. [CrossRef]

39. Covarrubias, C.; Trepiana, D. Synthesis of hybrid copper-chitosan nanoparticles with antibacterial activity against cariogenic Streptococcus mutans. Dent. Mater. J. 2018, 37, 379-384. [CrossRef]

40. Wu, J.; Weir, M.D. Development of novel self-healing and antibacterial dental composite containing calcium phosphate nanoparticles. J. Dent. 2015, 43, 317-326. [CrossRef]

41. Li, Y.; Hu, X. Novel magnetic nanoparticle-containing adhesive with greater dentin bond strength and antibacterial and remineralizing capabilities. Dent. Mater. 2018, 34, 1310-1322. [CrossRef]

42. Chen, C.; Weir, M.D. Antibacterial activity and ion release of bonding agent containing amorphous calcium phosphate nanoparticles. Dent. Mater. 2014, 30, 891-901. [CrossRef] 
43. Nabavizadeh, M.; Abbaszadegan, A. Antibiofilm efficacy of positively charged imidazolium-based silver nanoparticles in Enterococcus faecalis using quantitative real-time PCR. Jundishapur J. Microbiol. 2017, 10. [CrossRef]

44. Fan, W.; Wu, Y. Substantivity of Ag-Ca-Si mesoporous nanoparticles on dentin and its ability to inhibit Enterococcus faecalis. J. Mater. Sci. Mater. Med. 2016, 27. [CrossRef]

45. Bruniera, J.F.; Silva-Sousa, Y.T. Development of intracanal formulation containing silver nanoparticles. Braz. Dent. J. 2014, 25, 302-306. [CrossRef]

46. Martinez-Andrade, J.M.; Avalos-Borja, M. Dual function of EDTA with silver nanoparticles for root canal treatment-A novel modification. PLoS ONE 2018, 13, e0190866. [CrossRef]

47. Kesler Shvero, D.; Zaltsman, N. Lethal bacterial trap: Cationic surface for endodontic sealing. J. Biomed. Mater. Res. A 2016, 104, 427-434. [CrossRef]

48. Abbaszadegan, A.; Nabavizadeh, M. Positively charged imidazolium-based ionic liquid-protected silver nanoparticles: A promising disinfectant in root canal treatment. Int. Endod. J. 2015, 48, 790-800. [CrossRef]

49. Shrestha, A.; Kishen, A. Antibiofilm efficacy of photosensitizer-functionalized bioactive nanoparticles on multispecies biofilm. J. Endod. 2014, 40, 1604-1610. [CrossRef]

50. Shrestha, A.; Hamblin, M.R. Photoactivated rose bengal functionalized chitosan nanoparticles produce antibacterial/biofilm activity and stabilize dentin-collagen. Nanomedicine 2014, 10, 491-501. [CrossRef]

51. Charannya, S.; Duraivel, D. Comparative Evaluation of Antimicrobial Efficacy of Silver Nanoparticles and 2\% Chlorhexidine Gluconate When Used alone and in Combination Assessed Using Agar Diffusion Method: An In vitro Study. Contemp. Clin. Dent. 2018, 9, S204-S209. [CrossRef]

52. Halkai, K.R.; Mudda, J.A. Evaluation of Antibacterial Efficacy of Fungal-Derived Silver Nanoparticles against Enterococcus faecalis. Contemp. Clin. Dent. 2018, 9, 45-48. [CrossRef]

53. Halkai, K.R.; Mudda, J.A. Antibacterial Efficacy of Biosynthesized Silver Nanoparticles against Enterococcus faecalis Biofilm: An in vitro Study. Contemp. Clin. Dent. 2018, 9, 237-241. [CrossRef]

54. Halkai, K.R.; Mudda, J.A. Evaluation of antibacterial efficacy of biosynthesized silver nanoparticles derived from fungi against endo-perio pathogens Porphyromonas gingivalis, Bacillus pumilus, and Enterococcus faecalis. J. Conserv. Dent. 2017, 20, 398-404. [CrossRef]

55. Afkhami, F.; Akbari, S. Entrococcus faecalis Elimination in Root Canals Using Silver Nanoparticles, Photodynamic Therapy, Diode Laser, or Laser-activated Nanoparticles: An In Vitro Study. J. Endod. 2017, 43, 279-282. [CrossRef]

56. Chavez-Andrade, G.M.; Tanomaru-Filho, M. Cytotoxicity, genotoxicity and antibacterial activity of poly(vinyl alcohol)-coated silver nanoparticles and farnesol as irrigating solutions. Arch. Oral Biol. 2017, 84, 89-93. [CrossRef]

57. Monzavi, A.; Eshraghi, S. In vitro and ex vivo antimicrobial efficacy of nano-MgO in the elimination of endodontic pathogens. Clin. Oral Investig. 2015, 19, 349-356. [CrossRef]

58. Del Carpio-Perochena, A.; Bramante, C.M. Chelating and antibacterial properties of chitosan nanoparticles on dentin. Restor. Dent. Endod. 2015, 40, 195-201. [CrossRef]

59. Bukhari, S.; Kim, D. Novel Endodontic Disinfection Approach Using Catalytic Nanoparticles. J. Endod. 2018, 44, 806-812. [CrossRef]

60. Zheng, T.; Huang, X. A liquid crystalline precursor incorporating chlorhexidine acetate and silver nanoparticles for root canal disinfection. Biomater. Sci. 2018, 6, 596-603. [CrossRef]

61. Rodrigues, C.T.; de Andrade, F.B. Antibacterial properties of silver nanoparticles as a root canal irrigant against Enterococcus faecalis biofilm and infected dentinal tubules. Int. Endod. J. 2018, 51, 901-911. [CrossRef]

62. Schwass, D.R.; Lyons, K.M. Antimicrobial Activity of a Colloidal AgNP Suspension Demonstrated In Vitro against Monoculture Biofilms: Toward a Novel Tooth Disinfectant for Treating Dental Caries. Adv. Dent. Res. 2018, 29, 117-123. [CrossRef]

63. Wu, D.; Fan, W. Evaluation of the antibacterial efficacy of silver nanoparticles against Enterococcus faecalis biofilm. J. Endod. 2014, 40, 285-290. [CrossRef]

64. Guerreiro Tanomaru, J.M.; Storto, I. Radiopacity, pH and antimicrobial activity of Portland cement associated with micro- and nanoparticles of zirconium oxide and niobium oxide. Dent. Mater. J. 2014, 33, 466-470. [CrossRef] 
65. Guerreiro-Tanomaru, J.M.; Trindade-Junior, A. Effect of Zirconium Oxide and Zinc Oxide Nanoparticles on Physicochemical Properties and Antibiofilm Activity of a Calcium Silicate-Based Material. Sci. World J. 2014, 2014. [CrossRef]

66. Wang, L.; Xie, X. Novel bioactive root canal sealer to inhibit endodontic multispecies biofilms with remineralizing calcium phosphate ions. J. Dent. 2017, 60, 25-35. [CrossRef]

67. Seung, J.; Weir, M.D. A Modified Resin Sealer: Physical and Antibacterial Properties. J. Endod. 2018, 44, $1553-1557$. [CrossRef]

68. Del Carpio-Perochena, A.; Kishen, A. Antibacterial Properties of Chitosan Nanoparticles and Propolis Associated with Calcium Hydroxide against Single- and Multispecies Biofilms: An In Vitro and In Situ Study. J. Endod. 2017, 43, 1332-1336. [CrossRef]

69. Del Carpio-Perochena, A.; Kishen, A. Antibacterial Properties Associated with Chitosan Nanoparticle Treatment on Root Dentin and 2 Types of Endodontic Sealers. J. Endod. 2015, 41, 1353-1358. [CrossRef]

70. Louwakul, P.; Saelo, A. Efficacy of calcium oxide and calcium hydroxide nanoparticles on the elimination of Enterococcus faecalis in human root dentin. Clin. Oral Investig. 2017, 21, 865-871. [CrossRef]

71. Elshinawy, M.I.; Al-Madboly, L.A. Synergistic Effect of Newly Introduced Root Canal Medicaments; Ozonated Olive Oil and Chitosan Nanoparticles, Against Persistent Endodontic Pathogens. Front. Microbiol. 2018, 9, 1371. [CrossRef]

72. Afkhami, F.; Pourhashemi, S.J. Antibiofilm efficacy of silver nanoparticles as a vehicle for calcium hydroxide medicament against Enterococcus faecalis. J. Dent. 2015, 43, 1573-1579. [CrossRef]

73. Javidi, M.; Afkhami, F. Efficacy of a combined nanoparticulate/calcium hydroxide root canal medication on elimination of Enterococcus faecalis. Aust. Endod. J. 2014, 40, 61-65. [CrossRef]

74. Vazquez-Garcia, F.; Tanomaru-Filho, M. Effect of Silver Nanoparticles on Physicochemical and Antibacterial Properties of Calcium Silicate Cements. Braz. Dent. J. 2016, 27, 508-514. [CrossRef]

75. Nam, K.Y. Characterization and antimicrobial efficacy of Portland cement impregnated with silver nanoparticles. J. Adv. Prosthodont. 2017, 9, 217-223. [CrossRef]

76. Abramovitz, I.; Wisblech, D. Intratubular Antibacterial Effect of Polyethyleneimine Nanoparticles: An Ex Vivo Study in Human Teeth. J. Nanomater. 2015. [CrossRef]

77. Bahador, A.; Pourakbari, B. In vitro evaluation of the antimicrobial activity of nanosilver-mineral trioxide aggregate against frequent anaerobic oral pathogens by a membrane-enclosed immersion test. Biomed. J. 2015, 38, 77-83. [CrossRef]

78. Jonaidi-Jafari, N.; Izadi, M. The effects of silver nanoparticles on antimicrobial activity of ProRoot mineral trioxide aggregate (MTA) and calcium enriched mixture (CEM). J. Clin. Exp. Dent. 2016, 8, e22-e26. [CrossRef]

79. Barros, J.; Silva, M.G. Antibiofilm effects of endodontic sealers containing quaternary ammonium polyethylenimine nanoparticles. J. Endod. 2014, 40, 1167-1171. [CrossRef]

80. Li, P.; Tong, Z. Antibacterial and biological properties of biofunctionalized nanocomposites on titanium for implant application. J. Biomater. Appl. 2016, 31, 205-214. [CrossRef]

81. Wiedmer, D.; Petersen, F.C. Antibacterial effect of hydrogen peroxide-titanium dioxide suspensions in the decontamination of rough titanium surfaces. Biofouling 2017, 33, 451-459. [CrossRef]

82. Yang, Y.; Ren, S. Safety and efficacy of PLGA(Ag-Fe $\left.\mathrm{O}_{4}\right)$-coated dental implants in inhibiting bacteria adherence and osteogenic inducement under a magnetic field. Int. J. Nanomed. 2018, 13, 3751-3762. [CrossRef]

83. Rosenbaum, J.; Versace, D.L. Antibacterial properties of nanostructured $\mathrm{Cu}-\mathrm{TiO}_{2}$ surfaces for dental implants. Biomater. Sci. 2017, 5, 455-462. [CrossRef]

84. Shen, X.T.; Zhang, Y.Z. Effects on cytotoxicity and antibacterial properties of the incorporations of silver nanoparticles into the surface coating of dental alloys. J. Zhejiang Univ. Sci. B 2017, 18, 615-625. [CrossRef]

85. Divakar, D.D.; Jastaniyah, N.T. Enhanced antimicrobial activity of naturally derived bioactive molecule chitosan conjugated silver nanoparticle against dental implant pathogens. Int. J. Biol. Macromol. 2018, 108, 790-797. [CrossRef]

86. Jin, J.; Zhang, L. Ti-GO-Ag nanocomposite: The effect of content level on the antimicrobial activity and cytotoxicity. Int. J. Nanomed. 2017, 12, 4209-4224. [CrossRef] [PubMed]

87. Liu, W.; $\mathrm{Su}$, P. Synthesis of $\mathrm{TiO}_{2}$ nanotubes with $\mathrm{ZnO}$ nanoparticles to achieve antibacterial properties and stem cell compatibility. Nanoscale 2014, 6, 9050-9062. [CrossRef] 
88. Massa, M.A.; Covarrubias, C. Synthesis of new antibacterial composite coating for titanium based on highly ordered nanoporous silica and silver nanoparticles. Mater. Sci. Eng. C Mater. Biol. Appl. 2014, 45, 146-153. [CrossRef] [PubMed]

89. Matsubara, V.H.; Igai, F. Use of Silver Nanoparticles Reduces Internal Contamination of External Hexagon Implants by Candida albicans. Braz. Dent. J. 2015, 26, 458-462. [CrossRef]

90. Weng, S.; Zhao, X. Synthesis, characterization, antibacterial activity in dark and in vitro cytocompatibility of Ag-incorporated $\mathrm{TiO}_{2}$ microspheres with high specific surface area. J. Mater. Sci. Mater. Med. 2018, 29, 50. [CrossRef] [PubMed]

91. Pokrowiecki, R.; Zareba, T. In vitro studies of nanosilver-doped titanium implants for oral and maxillofacial surgery. Int. J. Nanomed. 2017, 12, 4285-4297. [CrossRef]

92. Liu, X.; Gan, K. Antibacterial properties of nano-silver coated PEEK prepared through magnetron sputtering. Dent. Mater. 2017, 33, e348-e360. [CrossRef] [PubMed]

93. Gyorgyey, A.; Janovak, L. Investigation of the in vitro photocatalytic antibacterial activity of nanocrystalline $\mathrm{TiO}_{2}$ and coupled $\mathrm{TiO}_{2} / \mathrm{Ag}$ containing copolymer on the surface of medical grade titanium. J. Biomater. Appl. 2016, 31, 55-67. [CrossRef] [PubMed]

94. Zhu, Y.; Cao, H. Hierarchical micro/nanostructured titanium with balanced actions to bacterial and mammalian cells for dental implants. Int. J. Nanomed. 2015, 10, 6659-6674. [CrossRef] [PubMed]

95. Vilarrasa, J.; Delgado, L.M. In vitro evaluation of a multispecies oral biofilm over antibacterial coated titanium surfaces. J. Mater. Sci. Mater. Med. 2018, 29, 164. [CrossRef]

96. Chen, P.; Wu, Z. Fabrication of a silver nanoparticle-coated collagen membrane with anti-bacterial and anti-inflammatory activities for guided bone regeneration. Biomed. Mater. 2018, 13. [CrossRef]

97. Memarzadeh, K.; Sharili, A.S. Nanoparticulate zinc oxide as a coating material for orthopedic and dental implants. J. Biomed. Mater. Res. A 2015, 103, 981-989. [CrossRef] [PubMed]

98. Abdulkareem, E.H.; Memarzadeh, K. Anti-biofilm activity of zinc oxide and hydroxyapatite nanoparticles as dental implant coating materials. J. Dent. 2015, 43, 1462-1469. [CrossRef]

99. Westas, E.; Hayashi, M. Bactericidal effect of photocatalytically-active nanostructured $\mathrm{TiO}_{2}$ surfaces on biofilms of the early oral colonizer, Streptococcus oralis. J. Biomed. Mater. Res. A 2017, 105, 2321-2328. [CrossRef]

100. Yeniyol, S.; Mutlu, I. Photocatalytical antibacterial activity of mixed-phase $\mathrm{TiO}_{2}$ Nanocomposite Thin Films against Aggregatibacter actinomycetemcomitans. BioMed Res. Int. 2015, 2015. [CrossRef]

101. Yang, T.; Qian, S. Cytocompatibility and antibacterial activity of titania nanotubes incorporated with gold nanoparticles. Colloids Surf. B Biointerfaces 2016, 145, 597-606. [CrossRef]

102. Liu, W.; Golshan, N.H. Selenium nanoparticles incorporated into titania nanotubes inhibit bacterial growth and macrophage proliferation. Nanoscale 2016, 8, 15783-15794. [CrossRef] [PubMed]

103. Besinis, A.; Hadi, S.D. Antibacterial activity and biofilm inhibition by surface modified titanium alloy medical implants following application of silver, titanium dioxide and hydroxyapatite nanocoatings. Nanotoxicology 2017, 11, 327-338. [CrossRef] [PubMed]

104. Zhong, X.; Song, Y. Titanium Surface Priming with Phase-Transited Lysozyme to Establish a Silver Nanoparticle-Loaded Chitosan/Hyaluronic Acid Antibacterial Multilayer via Layer-by-Layer Self-Assembly. PLoS ONE 2016, 11, e0146957. [CrossRef] [PubMed]

105. Li, Z.; Qiu, J. $\mathrm{TiO}_{2}$ nanorod arrays modified Ti substrates promote the adhesion, proliferation and osteogenic differentiation of human periodontal ligament stem cells. Mater. Sci. Eng. C Mater. Biol. Appl. 2017, 76, 684-691. [CrossRef] [PubMed]

106. Jia, L.; Qiu, J. $\mathrm{TiO}_{2}$ nanorod arrays as a photocatalytic coating enhanced antifungal and antibacterial efficiency of Ti substrates. Nanomedicine (Lond.) 2017, 12, 761-776. [CrossRef] [PubMed]

107. Yeniyol, S.; He, Z. Antibacterial Activity of As-Annealed $\mathrm{TiO}_{2}$ Nanotubes Doped with Ag Nanoparticles against Periodontal Pathogens. Bioinorg. Chem. Appl. 2014, 2014, 829496. [CrossRef]

108. Gao, A.; Hang, R. The effects of titania nanotubes with embedded silver oxide nanoparticles on bacteria and osteoblasts. Biomaterials 2014, 35, 4223-4235. [CrossRef]

109. Wood, N.J.; Jenkinson, H.F. Chlorhexidine hexametaphosphate nanoparticles as a novel antimicrobial coating for dental implants. J. Mater. Sci. Mater. Med. 2015, 26, 201. [CrossRef]

110. Hang, R.; Gao, A. Antibacterial activity and cytocompatibility of Cu-Ti-O nanotubes. J. Biomed. Mater. Res. A 2014, 102, 1850-1858. [CrossRef] 
111. Toodehzaeim, M.H.; Zandi, H. The Effect of CuO Nanoparticles on Antimicrobial Effects and Shear Bond Strength of Orthodontic Adhesives. J. Dent. (Shiraz) 2018, 19, 1-5.

112. Wang, X.; Wang, B. Antibacterial orthodontic cement to combat biofilm and white spot lesions. Am. J. Orthod. Dentofac. Orthop. 2015, 148, 974-981. [CrossRef]

113. Metin-Gursoy, G.; Taner, L. Nanosilver coated orthodontic brackets: In vivo antibacterial properties and ion release. Eur. J. Orthod. 2017, 39, 9-16. [CrossRef] [PubMed]

114. Sodagar, A.; Akhoundi, M.S.A. Effect of $\mathrm{TiO}_{2}$ nanoparticles incorporation on antibacterial properties and shear bond strength of dental composite used in Orthodontics. Dent. Press J. Orthod. 2017, 22, 67-74. [CrossRef] [PubMed]

115. Sodagar, A.; Bahador, A. Effect of Addition of Curcumin Nanoparticles on Antimicrobial Property and Shear Bond Strength of Orthodontic Composite to Bovine Enamel. J. Dent. (Tehran) 2016, 13, 373-382.

116. Sodagar, A.; Akhavan, A. Evaluation of the antibacterial activity of a conventional orthodontic composite containing silver/hydroxyapatite nanoparticles. Prog. Orthod. 2016, 17, 40. [CrossRef] [PubMed]

117. Degrazia, F.W.; Leitune, V.C. Effect of silver nanoparticles on the physicochemical and antimicrobial properties of an orthodontic adhesive. J. Appl. Oral Sci. 2016, 24, 404-410. [CrossRef] [PubMed]

118. Lee, S.J.; Heo, M. Preparation and characterization of antibacterial orthodontic resin containing silver nanoparticles. Appl. Surf. Sci. 2018, 432, 317-323. [CrossRef]

119. Zaltsman, N.; Kesler Shvero, D. Antibacterial Orthodontic Adhesive Incorporating Polyethyleneimine Nanoparticles. Oral Health Prev. Dent. 2017, 15, 245-250. [CrossRef]

120. Moreira, D.M.; Oei, J. A novel antimicrobial orthodontic band cement with in situ-generated silver nanoparticles. Angle Orthod. 2015, 85, 175-183. [CrossRef]

121. Ma, Y.; Zhang, N. Novel multifunctional dental cement to prevent enamel demineralization near orthodontic brackets. J. Dent. 2017, 64, 58-67. [CrossRef]

122. Zhang, N.; Weir, M.D. Orthodontic cement with protein-repellent and antibacterial properties and the release of calcium and phosphate ions. J. Dent. 2016, 50, 51-59. [CrossRef] [PubMed]

123. Zhang, N.; Chen, C. Antibacterial and protein-repellent orthodontic cement to combat biofilms and white spot lesions. J. Dent. 2015, 43, 1529-1538. [CrossRef] [PubMed]

124. Ramazanzadeh, B.; Jahanbin, A. Comparison of Antibacterial Effects of $\mathrm{ZnO}$ and $\mathrm{CuO}$ Nanoparticles Coated Brackets against Streptococcus Mutans. J. Dent. (Shiraz) 2015, 16, 200-205.

125. Hernandez-Gomora, A.E.; Lara-Carrillo, E. Biosynthesis of Silver Nanoparticles on Orthodontic Elastomeric Modules: Evaluation of Mechanical and Antibacterial Properties. Molecules 2017, 22, 1407. [CrossRef] [PubMed]

126. Prabha, R.D.; Kandasamy, R. Antibacterial nanosilver coated orthodontic bands with potential implications in dentistry. Indian J. Med. Res. 2016, 144, 580-586. [CrossRef]

127. Kachoei, M.; Nourian, A. Zinc-oxide nanocoating for improvement of the antibacterial and frictional behavior of nickel-titanium alloy. Nanomed. (Lond.) 2016, 11, 2511-2527. [CrossRef]

128. Mhaske, A.R.; Shetty, P.C. Antiadherent and antibacterial properties of stainless steel and NiTi orthodontic wires coated with silver against Lactobacillus acidophilus-An in vitro study. Prog. Orthod. 2015, 16, 40. [CrossRef]

129. Venugopal, A.; Muthuchamy, N. Incorporation of silver nanoparticles on the surface of orthodontic microimplants to achieve antimicrobial properties. Korean J. Orthod. 2017, 47, 3-10. [CrossRef]

130. Farhadian, N.; Usefi Mashoof, R. Streptococcus mutans counts in patients wearing removable retainers with silver nanoparticles vs those wearing conventional retainers: A randomized clinical trial. Am. J. Orthod. Dentofac. Orthop. 2016, 149, 155-160. [CrossRef]

131. Mousavi, S.A.; Ghotaslou, R. Antibacterial and antifungal effects of chitosan nanoparticles on tissue conditioners of complete dentures. Int. J. Biol. Macromol. 2018, 118 Pt A, 881-885. [CrossRef]

132. Yamada, R.; Nozaki, K. Ag nanoparticle-coated zirconia for antibacterial prosthesis. Mater. Sci. Eng. C Mater. Biol. Appl. 2017, 78, 1054-1060. [CrossRef] [PubMed]

133. Suganya, S.; Ahila, S.C. Evaluation and comparison of anti-Candida effect of heat cure polymethylmethacrylate resin enforced with silver nanoparticles and conventional heat cure resins: An in vitro study. Indian J. Dent. Res. 2014, 25, 204-207. [CrossRef] [PubMed]

134. Jo, J.K.; El-Fiqi, A. Rechargeable microbial anti-adhesive polymethyl methacrylate incorporating silver sulfadiazine-loaded mesoporous silica nanocarriers. Dent. Mater. 2017, 33, e361-e372. [CrossRef] [PubMed] 
135. Li, Z.; Sun, J. Effect of a denture base acrylic resin containing silver nanoparticles on Candida albicans adhesion and biofilm formation. Gerodontology 2016, 33, 209-216. [CrossRef] [PubMed]

136. Ginjupalli, K.; Alla, R.K. Antimicrobial activity and properties of irreversible hydrocolloid impression materials incorporated with silver nanoparticles. J. Prosthet. Dent. 2016, 115, 722-728. [CrossRef] [PubMed]

137. Nam, K.Y. Characterization and bacterial anti-adherent effect on modified PMMA denture acrylic resin containing platinum nanoparticles. J. Adv. Prosthodont. 2014, 6, 207-214. [CrossRef] [PubMed]

138. Kamonkhantikul, K.; Arksornnukit, M. Antifungal, optical, and mechanical properties of polymethylmethacrylate material incorporated with silanized zinc oxide nanoparticles. Int. J. Nanomed. 2017, 12, 2353-2360. [CrossRef] [PubMed]

139. Alrahlah, A.; Fouad, H. Titanium Oxide $\left(\mathrm{TiO}_{2}\right) /$ Polymethylmethacrylate (PMMA) Denture Base Nanocomposites: Mechanical, Viscoelastic and Antibacterial Behavior. Materials (Basel) 2018, 11, 1096. [CrossRef] [PubMed]

140. Totu, E.E.; Nechifor, A.C. Poly(methyl methacrylate) with $\mathrm{TiO}_{2}$ nanoparticles inclusion for stereolitographic complete denture manufacturing-The fututre in dental care for elderly edentulous patients? J. Dent. 2017, 59, 68-77. [CrossRef] [PubMed]

141. Chen, R.; Han, Z. Antibacterial activity, cytotoxicity and mechanical behavior of nano-enhanced denture base resin with different kinds of inorganic antibacterial agents. Dent. Mater. J. 2017, 36, 693-699. [CrossRef] [PubMed]

142. Gad, M.M.; Al-Thobity, A.M. Inhibitory effect of zirconium oxide nanoparticles on Candida albicans adhesion to repaired polymethyl methacrylate denture bases and interim removable prostheses: A new approach for denture stomatitis prevention. Int. J. Nanomed. 2017, 12, 5409-5419. [CrossRef] [PubMed]

143. Fathima, J.B.; Pugazhendhi, A. Synthesis and characterization of $\mathrm{ZrO}_{2}$ nanoparticles-antimicrobial activity and their prospective role in dental care. Microb. Pathog. 2017, 110, 245-251. [CrossRef] [PubMed]

144. Sodagar, A.; Khalil, S. Antimicrobial properties of poly (methyl methacrylate) acrylic resins incorporated with silicon dioxide and titanium dioxide nanoparticles on cariogenic bacteria. J. Orthod. Sci. 2016, 5, 7-13. [CrossRef] [PubMed]

145. Garner, S.J.; Nobbs, A.H. An antifungal coating for dental silicones composed of chlorhexidine nanoparticles. J. Dent. 2015, 43, 362-372. [CrossRef] [PubMed]

146. Lee, J.H.; Jo, J.K. Nano-graphene oxide incorporated into PMMA resin to prevent microbial adhesion. Dent. Mater. 2018, 34, e63-e72. [CrossRef] [PubMed]

147. Wang, L.; Xie, X. A protein-repellent and antibacterial nanocomposite for Class-V restorations to inhibit periodontitis-related pathogens. Mater. Sci. Eng. C Mater. Biol. Appl. 2016, 67, 702-710. [CrossRef] [PubMed]

148. Wang, L.; Melo, M.A. Novel bioactive nanocomposite for Class-V restorations to inhibit periodontitis-related pathogens. Dent. Mater. 2016, 32, e351-e361. [CrossRef]

149. Wang, L.; Li, C. Novel multifunctional dental bonding agent for Class-V restorations to inhibit periodontal biofilms. Rsc Adv. 2017, 7, 29004-29014. [CrossRef]

150. Wang, L.; Xie, X. Effect of bioactive dental adhesive on periodontal and endodontic pathogens. J. Mater. Sci. Mater. Med. 2016, 27. [CrossRef]

151. Ahrari, F.; Eslami, N. The antimicrobial sensitivity of Streptococcus mutans and Streptococcus sangius to colloidal solutions of different nanoparticles applied as mouthwashes. Dent. Res. J. (Isfahan) 2015, 12, 44-49.

152. Khan, S.T.; Ahamed, M. Anti-biofilm and antibacterial activities of zinc oxide nanoparticles against the oral opportunistic pathogens Rothia dentocariosa and Rothia mucilaginosa. Eur. J. Oral Sci. 2014, 122, 397-403. [CrossRef]

153. Mousa, H.M.; Abdal-Hay, A. A Multifunctional Zinc Oxide/Poly(Lactic Acid) Nanocomposite Layer Coated on Magnesium Alloys for Controlled Degradation and Antibacterial Function. ACS Biomater. Sci. Eng. 2018, 4, 2169-2180. [CrossRef]

154. El-Rashidy, A.A.; Waly, G. Antibacterial activity and biocompatibility of zein scaffolds containing silver-doped bioactive glass. Biomed. Mater. 2018, 13, 065006. [CrossRef]

155. Besinis, A.; De Peralta, T. Inhibition of biofilm formation and antibacterial properties of a silver nano-coating on human dentin. Nanotoxicology 2014, 8, 745-754. [CrossRef]

156. Halkai, K.R.; Mudda, J.A. Biosynthesis, Characterization and Antibacterial Efficacy of Silver Nanoparticles Derived from Endophytic Fungi against, P. gingivalis. J. Clin. Diagn. Res. 2017, 11, zc92-zc96. [CrossRef] 
157. Mendes-Gouvea, C.C.; do Amaral, J.G. Sodium trimetaphosphate and hexametaphosphate impregnated with silver nanoparticles: Characteristics and antimicrobial efficacy. Biofouling 2018, 34, 299-308. [CrossRef]

158. Panacek, A.; Smekalova, M. Silver nanoparticles strongly enhance and restore bactericidal activity of inactive antibiotics against multiresistant Enterobacteriaceae. Colloids Surf B Biointerfaces 2016, 142, 392-399. [CrossRef]

159. Niska, K.; Knap, N. Capping Agent-Dependent Toxicity and Antimicrobial Activity of Silver Nanoparticles: An In Vitro Study. Concerns about Potential Application in Dental Practice. Int. J. Med. Sci. 2016, 13, 772-782. [CrossRef]

160. Scarpelli, B.B.; Punhagui, M.F. In Vitro Evaluation of the Remineralizing Potential and Antimicrobial Activity of a Cariostatic Agent with Silver Nanoparticles. Braz. Dent. J. 2017, 28, 738-743. [CrossRef]

161. Panpaliya, N.P.; Dahake, P.T. In vitro evaluation of antimicrobial property of silver nanoparticles and chlorhexidine against five different oral pathogenic bacteria. Saudi Dent. J. 2018. [CrossRef]

162. Priyadarshini, B.M.; Fawzy, A.S. Potentiating the antibacterial effect of silver nanospheres by surface-capping with chlorhexidine gluconate. J. Nanopart. Res. 2017, 19. [CrossRef]

163. Sanchez, M.C.; Toledano-Osorio, M. Antibacterial effects of polymeric PolymP-n Active nanoparticles. An. in vitro biofilm study. Dent. Mater. 2018. [CrossRef] [PubMed]

164. Kivanc, M.; Barutca, B. Effects of hexagonal boron nitride nanoparticles on antimicrobial and antibiofilm activities, cell viability. Mater. Sci. Eng. C Mater. Biol. Appl. 2018, 91, 115-124. [CrossRef] [PubMed]

165. Soekanto, S.A.; Marpaung, L.J. Efficacy of propolis fluoride and nano silver fluoride for inhibition of streptococcus mutans and enterococcus faecalis biofilm formation. Int. J. Appl. Pharm. 2017, 9, 51-54. [CrossRef]

166. Ribeiro Targino, A.G.; Pelagio Flores, M.A. An innovative approach to treating dental decay in children. A new anti-caries agent. J. Mater. Sci. Mater. Med. 2014, 25, 2041-2047. [CrossRef] [PubMed]

167. Freire, P.L.L.; Albuquerque, A.J.R. AgNPs: The New Allies against S. Mutans Biofilm-A Pilot Clinical Trial and Microbiological Assay. Braz. Dent. J. 2017, 28, 417-422. [CrossRef]

168. Mackevica, A.; Olsson, M.E. The release of silver nanoparticles from commercial toothbrushes. J. Hazard. Mater. 2017, 322, 270-275. [CrossRef]

169. Do Nascimento, C.; Paulo, D.F. Microbial diversity of the supra- and subgingival biofilm of healthy individuals after brushing with chlorhexidine- or silver-coated toothbrush bristles. Can. J. Microbiol. 2014, 61, 112-123. [CrossRef]

170. Ikono, R.; Mardliyati, E. Chitosan-PRP nanosphere as a growth factors slow releasing device with superior antibacterial capability. Biomed. Phys. Eng. Express 2018, 4. [CrossRef]

171. Lee, H.J.; Kim da, E. pH-Responsive mineralized nanoparticles as stable nanocarriers for intracellular nitric oxide delivery. Colloids Surf. B Biointerfaces 2016, 146, 1-8. [CrossRef]

172. Rencber, S.; Karavana, S.Y. Development, characterization, and in vivo assessment of mucoadhesive nanoparticles containing fluconazole for the local treatment of oral candidiasis. Int. J. Nanomed. 2016, 11, 2641-2653. [CrossRef]

(C) 2019 by the authors. Licensee MDPI, Basel, Switzerland. This article is an open access article distributed under the terms and conditions of the Creative Commons Attribution (CC BY) license (http://creativecommons.org/licenses/by/4.0/). 